\title{
INTERAKCJE SZTUK PLASTYCZNYCH \\ Z JĘZYKIEM I LITERATURĄ NA FESTIWALU \\ LITERY - SLOWO, LITERA, ZNAK
}

TERESA DoBRZYŃSKA

Instytut Badań Literackich PAN

Institute of Literary Research,

Polish Academy of Sciences in Warsaw

dobter@hotmail.com

ORCID: 0000-0002-7078-9209

\section{WYDARZENIA FESTIWALOWE}

Współdziałanie słowa i obrazu zachodzi w jednej kompozycji dzięki semiotycznej naturze obu łączonych w ten sposób dziedzin - i nie jest to zjawisko rzadkie w świecie sztuki. Można przywołać wiele dawnych i nowszych przykładów dzieł malarskich, grafik czy kolaży włączających napisy do obrazów ${ }^{1}$. Także w czasach współczesnych takie połączenia stanowią przed-

${ }^{1}$ Można wymienić wiele kompozycji malarskich, w których występuje takie połączenie heterogenicznych znaków; zob. np. ikony bizantyjskie z imionami świętych i archaniołów towarzyszącymi postaciom, romańskie oraz gotyckie freski i ołtarze z inskrypcjami utrwalającymi słowa Chrystusa czy inne ważne treści sakralne, iluminowane kodeksy z pięknie zdobionymi inicjałami. Intrygującą grę znaczeniową wprowadza barokowy malarz Nicolas Poussin, przedstawiający napis Et in Arcadia ego wyryty na grobowcu (zob. zwłaszcza drugą wersję: z okresu 1638-1640). Spośród późniejszych malarzy słowa pomysłowo wkomponowane w obraz pojawiają się m.in. u Joana Miró, René Magritte’a (np. przedstawienie fajki na obrazie z napisem „To nie jest fajka”). Urywki tekstów włączał też do swych martwych natur Pablo Picasso, a plansze $z$ napisami, fragmenty drukowanych reklam, etykiet lub gazet wykorzystywali w obrazach lub kolażach przedstawiciele popartu. Szerszy rys historyczny tej konwencji malarskiej i analizę funkcji napisów łączonych z obrazami przedstawił Mieczysław Wallis; zob. M. Wallis, Napisy w malarstwie, [w:] idem, Wybór pism estetycznych, wybór, wstęp i oprac. T. Pękala, Kraków 2004. 
miot działań twórczych, i to coraz bardziej odkrywczych z uwagi na rosnące zróżnicowanie sztuk wizualnych i nowatorskie środki techniczne wykorzystywane przez artystów. Łączenie obrazów z napisami pojawia się też w sferze sztuki użytkowej, np. w reklamie, w aranżacji wystaw i w modzie, a zainteresowanie plastycznymi walorami liter widać tak ze strony artystów plastyków, jak i edytorów ${ }^{2}$.

Analizując niejednorodne kompozycje słowno-obrazowe, trzeba brać pod uwagę zarówno rozmaitość ich tworzywa i odmienny potencjał znaczeniowy poszczególnych środków wyrazu, jak też zróżnicowane sposoby łącznego wykorzystywania heterogenicznych znaków w przekazach artystycznych. Tego typu dzieła, powstające na pograniczu sztuk plastycznych i sfery języka, stanowią jedną z odmian „tekstów kultury”. Tym terminem określa się wszelkie spójne układy znaków niosące - podobnie jak teksty werbalne - pewien całościowy sens.

„Tekst kultury” to pojęcie kluczowe dla badań wytworów kultury, dobrze zadomowione w pracach semiotyków i antropologów ${ }^{3}$. Umożliwia

2 Dużym wydarzeniem poświęconym typografii edytorskiej była wystawa Lettra - 2018, znak/litera. Tworzywo litera, zorganizowana jesienią 2018 roku w Bibliotece Jagiellońskiej w Krakowie. W wystawie uczestniczyło 35 twórców. Tekst zamieszczony na plakacie głosił: „Prezentowane na wystawie dzieła graficzne obejmują książki artystyczne, obiekty trójwymiarowe, szkice i rysunki. Litera tutaj nie jest ograniczeniem, a jedynie inspiracją do kreatywnych działań, które ukazują potęgę wyobraźni artystów. Forma i materia graficzna litery odzwierciedla osobowość twórcy. Litera jest znakiem, symbolem, jest ona pisana, kaligrafowana, typograficzna - czcionka, zdigitalizowana - font. Ma różne postaci, ale też przeznaczenie. Jest tekstem, tytułem, szyldem, znakiem, inicjałem, nazwą".

3 Pojęcie "tekstu kultury” wprowadzili na szeroką skalę do analiz semiotycznych przedstawiciele szkoły moskiewsko-tartuskiej: Władimir N. Toporow, Borys A. Uspienskij, Jurij M. Łotman i in., obejmując nim werbalne i niewerbalne dzieła sztuki, przedmioty i kompleksy zjawisk nacechowane znaczeniowo, obrzędy religijne i rytuały świeckie (zob. B. Żyłko, Semiotyka kultury. Szkoła tartusko-moskiewska, Gdańsk 2009). Pionierską rolę w procesie adaptacji tego pojęcia do potrzeb badań kultury odegrał Michaił Bachtin, który brał już pod uwagę „wszelki spójny kompleks znaków" (zob. M. Bachtin, Estetyka twórczości słownej, tłum. D. Ulicka, oprac. i wstęp E. Czaplejewicz, Warszawa 1986, s. 403). W Polsce termin „tekst kultury” spopularyzował Stefan Żółkiewski (zob. m.in. S. Żółkiewski, 
ono szersze spojrzenie na rozmaite przekazy znakowe i analizowanie ich funkcji w różnych dziedzinach życia społecznego. Tekstami kultury są symboliczne zachowania i obrzędy, a w obrębie interesującego nas pola sztuki - sztuki plastycznej wchodzącej w alianse z językiem i literaturą - pojęcie to pozwala traktować łącznie dzieła malarskie wykorzystujące elementy werbalne, sztukę plakatu, ilustracje książkowe i opracowania graficzne książek, murale czy instalacje artystyczne itp., itd. Ułatwia też interpretację hybrydycznych gatunków czy utworów słowno-obrazowych powstających w obrębie literatury ${ }^{4}$.

Takim właśnie zjawiskom z dziedziny pogranicza sztuki i języka poświęcony był Festiwal Litery - Słowo, litera, znak, zorganizowany z inicjatywy Joanny Koreckiej w warszawskim Domu Artysty Plastyka w początkach marca 2020 roku. Kuratorka festiwalu zebrała na wystawie ponad 40 prac reprezentujących różne techniki plastyczne i w rozmaity sposób nawiązujących do wskazanych kluczowych pojęć. Zaplanowała też kilka spotkań festiwalowych, m.in. wieczór poezji i wykłady literaturoznawców zajmujących się problematyką przekazów powstałych na styku „słowo/obraz”. Niestety, przebieg festiwalu został w połowie zakłócony przez szerzącą się epidemię koronawirusa, co zmusiło organizatorów do odwołania kilku imprez, ale sama wystawa i pierwsze zrealizowane spotkania dowiodły, że szeroko rozumiany temat obecności znaków językowych w sztuce wizualnej znajduje odbicie w pracach wielu twórców, a zamysł interdyscyplinarnego

Kultura, socjologia, semiotyka literacka, Warszawa 1979; idem, Teksty kultury. Studia, Warszawa 1988). Pojęcie to zostało zasymilowane przez literaturoznawstwo otwarte na perspektywę kulturową i włączone do zasobu powszechnie stosowanych terminów teoretycznoliterackich oraz do programu nauczania licealnego (zob. Słownik pojęć i tekstów kultury, red. E. Szczęsna, Warszawa 2002, hasło: Tekst kultury, s. 307). Umożliwia ono opis różnorodnych powiązanych ze sobą zjawisk w sposób zintegrowany, przy użyciu jednolitych kategorii.

${ }^{4}$ Hybrydy literacko-obrazowe, wykorzystujące różne formy zespoleń treści werbalnych i wizualnych, omawia w swej książce Grzegorz Grochowski; zob. G. Grochowski, Pamięć gatunków. Ponowoczesne dylematy atrybucji gatunkowej, Warszawa 2018, rozdz. Na styku kodów. O literackich użyciach znaków ikonicznych, s. 142-174. 
spotkania wokół tej problematyki w gronie artystów plastyków i badaczy literatury znalazł zainteresowanie w obu środowiskach.

W festiwalu wzięło udział kilkunastu artystów z dziedziny sztuk plastycznych ${ }^{5}$. Akces (częściowo tylko zrealizowany z powodu rozwoju epidemii) zgłosili też badacze literatury z Instytutu Badań Literackich PAN, Uniwersytetu Warszawskiego oraz Uniwersytetu Kardynała Stefana Wyszyńskiego.

Okazją do spotkania licznie reprezentowanych środowisk artystów i literaturoznawców stał się przede wszystkim wernisaż z udziałem chóru Bemcanto; jego występ poprzedziły ćwiczenia wokalne „o-i-a-u”, które wybrzmiewając wśród dzieł plastycznych przedstawiających różnie wyobrażane i przetwarzane litery - stanowiły swego rodzaju pomysłowy i zabawny kontrapunkt.

Kolejne spotkanie festiwalowe poświęcone zostało językowi, a zrealizowano je w dwóch odsłonach. Pierwsza to wykład piszącej te słowa na temat różnych typów znaczeń zakodowanych w języku i w wypowiedziach. Mówiąc o znakowej materii mowy, wykorzystywanej i przetwarzanej w tekstach literackich, referentka podkreślała, iż kumulacja tych zjawisk zachodzi w poezji, której bogate możliwości sensotwórcze służą wyrażaniu fundamentalnych, jak też najbardziej intymnych potrzeb człowieka.

W drugiej części wieczoru w galerii wypełnionej obrazami zabrzmiała poezja. Wiersze recytował przy świecach poeta, tłumacz i eseista Tristan Korecki, który nadał swemu występowi formę teatru poetyckiego, wykorzystując bogaty stylistyczny potencjał żywego słowa wzmocnionego wyrazistym gestem. Obrazowe słowo poezji, poddawane w utworach Koreckiego wielu innowacjom słowotwórczym i odsłaniające swe zakorzenienie w przeszłości języka, w żywiole mowy o wyraźnych rysach idiolektalnych, objawiło swe walory w sugestywnych recytacjach, które nadawały artykulacyjny kształt „gestom fonicznym” wpisanym w niebanalną, pełną eksklamacji tkankę tekstu.

5 Lista artystów, którzy wystawili swe prace w ramach festiwalu, dołączona została na końcu artykułu. 


\section{LITERY I SŁOWA W OBRAZACH}

Kompozycje plastyczne przedstawiane na wystawie przyciągały uwagę rozmaitością odniesień do tematu festiwalu i artystyczną pomysłowością, a ich rysem wspólnym było pierwszoplanowe lub przynajmniej wyraźnie wyeksponowane użycie motywów językowych. Analizę prac pod kątem zastosowanych technik i artystyczną ocenę pozostawiam krytykom sztuki, skupię się natomiast głównie na kwestiach semiotycznych, zwłaszcza na tych związanych ze współdziałaniem mediów, bo to właśnie przesądza o wyjątkowym charakterze owych niejednorodnych tekstów kultury. Zastrzegam równocześnie, że będzie to interpretacja uwarunkowana nastawieniem badacza języka i literatury, zdradzająca analogie z praktyką analiz teoretycznoliterackich, a kolejność analizy zostanie podporządkowana klasyfikacji uwzględniającej udział zjawisk językowych w kompozycjach plastycznych.

Tym, co łączy sferę języka z dziedziną malarstwa czy grafiki, jest przede wszystkim zapis słów i głosek, a więc omawianie prac zacznę od plastycznych przedstawień liter czy innych rodzajów notacji. Niektóre kompozycje spełniające te kryteria przypominają sposobem ujęcia przedmioty użytkowe. W pracach tych można odnaleźć ślady fundamentalnej dyskusji nad statusem dzieła sztuki, a są one ciekawe także ze względu na zachodzące w nich przewartościowania natury semiotycznej i na swoisty typ odbioru, jaki mogą prowokować.

Kompozycja Bożenny Leszczyńskiej HAAB (il. 1-4) składa się z czterech plansz przedstawiających różne koncepcje pisma: ideograficzne pismo Majów, hieroglify egipskie, alfabet ugarycki (zapis klinowy) i piktogramy prekolumbijskie. Potraktowana jako przedmiot użytkowy tablica ta mogłaby służyć do celów dydaktycznych: demonstrować różne wynalazki pisma, a zatem pełnić funkcję poznawczą. Została jednak przeniesiona w przestrzeń sztuki, objawia więc swe walory wizualne i wyzwala szczególne reakcje odbiorcze. Przyciągają uwagę zróżnicowane i intrygujące kształty znaków tworzących łącznie wymyślne układy graficzne, a ich zestawienie budzi głębsze refleksje na temat znakowej funkcji tych przedstawień.

W artystycznym ujęciu Leszczyńskiej, realizowanym w środowisku kulturowym oddalonym czasowo i przestrzennie od kultur, które stworzyły prezentowane systemy zapisu, cztery odmienne systemy notacji komunikatów językowych zostają oderwane od swych podstawowych ról semantycznych. Z kategorii konwencjonalnych znaków symbolicznych, funkcjonujących 
w poszczególnych kulturach, przeszły po wiekach do sfery niezrozumiałych kształtów. Tak się dzieje przede wszystkim z notacją literową; ideogramy (oparte $\mathrm{w}$ dużej mierze na związkach ikonicznych znaku z desygnatem) wydają się trwalej zachowywać naturę znaków i kuszą przygodnego deszyfratora swymi dającymi się w pewnym stopniu rozpoznać związkami z rzeczywistością, której elementy mogą reprezentować. Ale i one dla kogoś z innej kultury są znaczeniowo niejasne, pozbawione swych podstawowych mocy symbolicznych utrwalonych w konwencjonalnym systemie notacji, właściwym dla ich rodzimych kultur. W tych okolicznościach przedstawienia dawnych znaków pisma tracą związek ze swymi znaczeniami i przestają pełnić funkcję symboli. Jednakże nadal mogą wyzwalać innego typu semiozę: zachowują mianowicie nacechowanie indeksalne motywowane przez ich związek z pierwotnym środowiskiem. Rozpoznanie poszczególnych przedstawień graficznych jako nośników znaczeń indeksalnych wymaga jednak dodatkowej wiedzy na temat pochodzenia znaków. Jeśli zabraknie tych informacji, tekst kultury utraci nabyte nacechowania, a w konsekwencji ulegnie ostatecznej desemantyzacji i sprowadzony zostanie do roli przedmiotu - graficznego ornamentu.

Kompozycja Leszczyńskiej, ukazująca zestawienie różnych rodzajów pisma - dostępna współczesnemu odbiorcy jedynie na poziomie znaczeń indeksalnych - skłania do myślenia o równoległych, a zarazem niezależnych dążeniach różnych ludów do stworzenia systemów notacji. Nasuwa się refleksja, że choć te systemy znaków pisma są odmienne, motywowane rozmaitymi lokalnymi uwarunkowaniami, to potrzeba utrwalania przekazu językowego jest wspólna ludziom różnych kultur, różnych epok. Zespolenie kilku systemów notacji w jednej kompozycji graficznej wyraża więc paradoks jedności w wielości, a płaskie plansze zestawione na obrazie wyzwalają ruch w czasie i przestrzeni, co znajduje metaforyczny wyraz w tytule kompozycji: $H A A B$ to nazwa kalendarza Majów opisującego przepływ czasu i jego cykliczność.

Analizowany przypadek dobrze reprezentuje też inne zjawisko, które dotyczy wielu dzieł sztuki nowoczesnej, a podobne oscylacje: zwykły przedmiot / obiekt estetyczny, są znamienne dla współczesnej kultury. Obcując z takimi obiektami o dwuznacznym statusie, trzeba pamiętać, iż to właśnie w modernizmie nastąpił „przewrót kopernikański” zmieniający zasadę określania tożsamości przedmiotu artystycznego. Jak dowodzą teoretycy - a opinię tę 

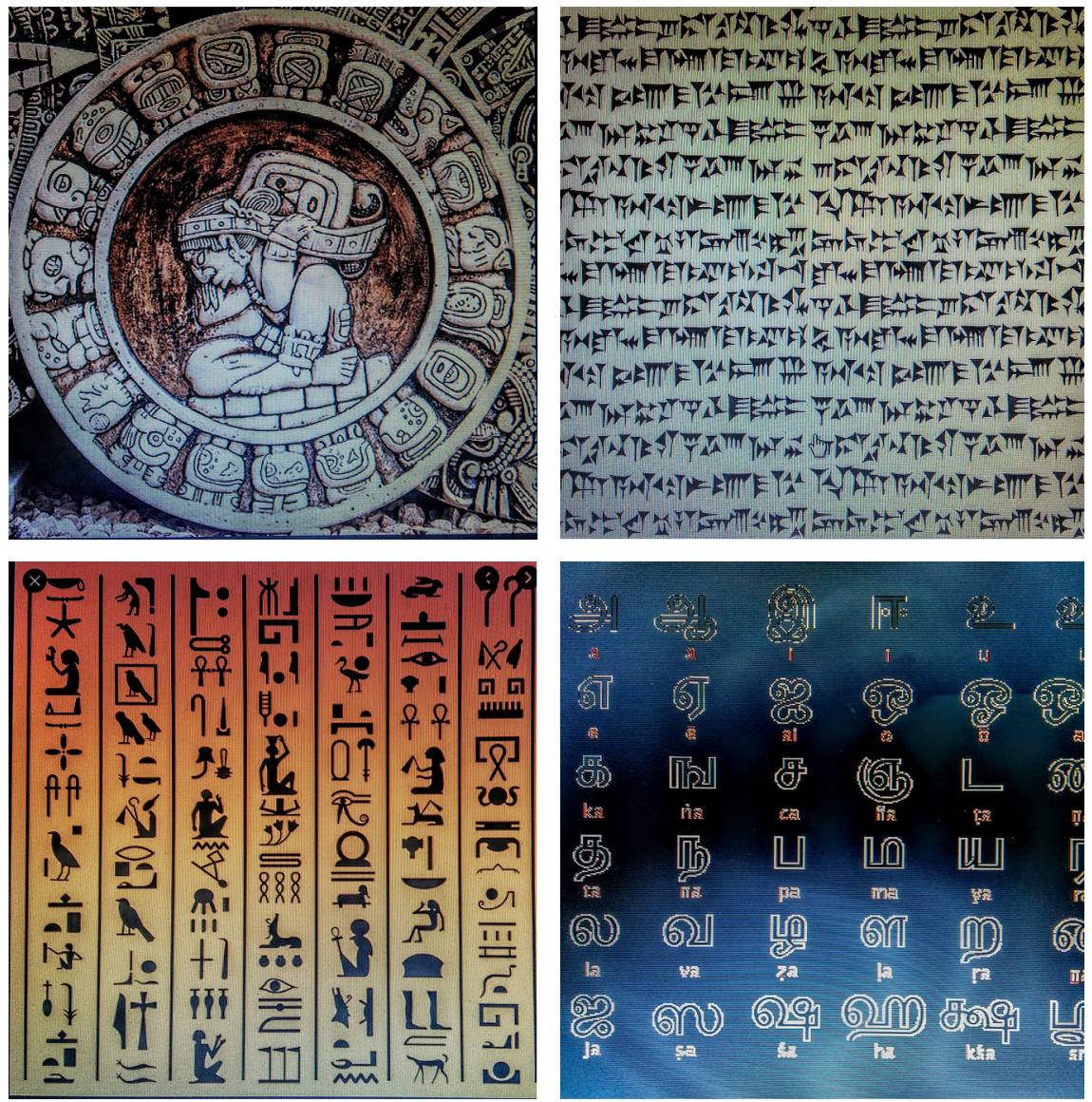

Il. 1-4. Kompozycja Bożenny Leszczyńskiej HAAB

potwierdzają analizujący istotę swej sztuki artyści - dzieło sztuki zyskuje swój status nie ze względu na obiektywne cechy formalne, na takie czy inne wyposażenie stylistyczne; te właściwości jedynie potwierdzają jego artystyczny status, ale są pochodne i wtórne wobec podstawowych zachodzących w nim przeobrażeń semiotycznych. O tożsamości dzieła sztuki decyduje funkcja nadana mu przez autora i sposób traktowania przedmiotu podjęty przez odbiorcę, towarzyszy zaś temu wprowadzenie danego dzieła w specjalną, zinstytucjonalizowaną przestrzeń przekazów artystycznych. 
Przetworzone semiotycznie dzieło staje się znakiem ikonicznym - wyrażeniem cudzysłowowym, a więc obiektem ujętym z pozycji meta- ${ }^{6}$. Przedmiot użyty z intencją, która zapewnia mu status obiektu estetycznego, odrywa się od swych elementarnych funkcji pozaartystycznych i staje w jednym rzędzie z innymi dziełami sztuki. Jako taki zyskuje zdolność wyrażania sensu i oczekuje na aktywny odbiór, wchodząc z odbiorcą w szczególną relację: prowokuje do odczytań i do zestawień porównawczych, a więc jest bodźcem wyzwalającym dialog ${ }^{7}$. Ukształtowanie dzieła nabiera w tych okolicznościach szczególnej ważności, ponieważ to właśnie w nim kryją się nośniki znaczeń.

Podobne refleksje budzi grafika autorstwa Joanny Koreckiej zatytułowana Nie ma takiego samego (il. 5), przenosząca widza na swojski teren alfabetu łacińskiego. Owa kompozycja, zapełniona równymi rzędami kilkudziesięciu odmiennych zapisów litery „W”, przypomina użytkowy zestaw wzorów pisma, ale zmieniono jej status, nadając grafice funkcję estetyczną. Oznaką tej zmiany jest umieszczenie planszy na wystawie, czyli włączenie jej w zinstytucjonalizowaną przestrzeń sztuki. Wyrazistym sygnałem artystycznej funkcji dzieła jest opatrzenie kompozycji tytułem, co wyzwala i ukierunkowuje odczytanie jej sensu. W pewnych warunkach - takich, z jakimi

${ }^{6}$ W obrębie literaturoznawstwa rozstrzygającą opinię w tej kwestii wypowiedział Richard Ohmann zwracający uwagę na szczególny status utworów literackich, które od zwykłych wypowiedzi spełniających funkcje praktyczne różnią się intencją traktowania ich jako tworów mimetycznych, naśladujących typowe wypowiedzi. Badacz ujął swój pogląd w następujących słowach: „Quasi-akty mowy są podane czytelnikowi do kontemplacji”; „literatura jest zwolniona z normalnych powiązań, które obowiązują między wypowiedzią a światem zewnętrznym"; R. Ohmann, Akty mowy a definicja literatury, tłum. B. Kowalik, W. Krajka, „Pamiętnik Literacki” 1980, z. 2, s. 267.

7 „Maszynami dialogowymi” nazywa teksty Wincenty Grajewski, który tę dialogowość tekstów opisuje następująco: „Tekst widziany jako maszyna dialogowa uwrażliwia nas na moment specyficznej interwencji, której przedmiotem jest dyskurs odbiorcy tekstu. Tekst bowiem nie jest czymś pasywnie przyjmowanym, lektura tekstu jest zdarzeniem w dyskursie czytelnika. Tekst odpowiada nie tyle za »swój« sens, co za działania semantyczne, do których skłoni czytelnika [...]”; W. Grajewski, Maszyny dialogowe. Szkice teoretycznoliterackie, Kraków 2003, s. 29 (podkr. oryginalne). 
mamy tu do czynienia - użytkowy tekst kultury, jakim jest „wzornik”, przeistacza się w znaczący przekaz artystyczny i może być poddany odpowiedniej interpretacji. Zaciera się przy tym pierwotna symboliczna funkcja zobrazowanej litery - jej konwencjonalny związek z głoską $w$, a na plan pierwszy wysuwają się indeksalne wartości różnych wariantów zapisu tej głoski. To one stają się głównym materiałem eksploracji i wokół nich koncentrują się nowe sensy. Biorąc to pod uwagę, odczytajmy możliwe znaczenia tej kompozycji graficznej.

Otóż, analizując treść planszy, można dojść do wniosku, że (skądinąd banalny) pomysł uszeregowania różnych form tej samej litery odsłania - doświadczany w codziennym ludzkim przeżyciu i analizowany przez wielu myślicieli - paradoks jedności w różnorodności ${ }^{8}$. Idąc dalej: owo proste zestawienie graficznych wariantów „W” stawia przed oczyma zagadkową odmienność bytów spełniających tę samą funkcję, a mimo wszystko odrębnych i indywidualnych, uwarunkowanych niejasnymi zależnościami od twórców poszczególnych stylów pisma i różnych środowisk. Litery ułożone w równe szeregi - podlegają przymusowi układu i mierzą się z redundancją zbędnych powtórzeń, demonstrując równocześnie swą inność w stosunku do sąsiednich znaków i swą niepowtarzalność. I wreszcie - tak skomponowane studium otwiera możliwość szukania analogii w świecie

8 Dylemat ten dyskutowany jest m.in. w studiach włączonych do zbiorów: Resemblance and Difference. The Problem of Identity - Podobe i različe. Problema identičnosti, eds. T. Dobrzyńska, R. Kuncheva, foreword T. Dobrzyńska, Warsaw Sofia 2015; Byt. Badania interdyscyplinarne, cz. 1: Różnica - tożsamość - zmiana, red. M. Saganiak, A. Kozłowska, M. Werner, Warszawa 2019. 
ludzkim. Plastycznymi środkami zdaje się wyrażać idee, które pojawiają się w toczonych przez humanistów dyskusjach wokół kategorii podmiotu i tożsamości ${ }^{9}$.

Jeśli przyjrzeć się dokładniej uszeregowanym literom, to nie wszystkie okazują się jednak wyraźnie odmienne. Pojawiają się większe „podobieństwa rodzinne”, a zdarzają się też „bliźniaki”, co traktowałabym jako żartobliwie ironiczny komentarz do ludzkiej potrzeby wyjątkowości.

Zaprezentowany kierunek refleksji wskazał na możliwość potraktowania analizowanej kompozycji w sposób alegoryczny - jako swego rodzaju diagramu relacji międzyludzkich, nadbudowanego nad indeksalnymi wartościami przedstawianych wariantów litery.

Wizualne przedstawienia głosek pojawiają się w licznych pracach Koreckiej zgromadzonych na wystawie - od tych najbardziej oczywistych graficznych studiów liter po przypominające sztukę origami kompozycje plastyczne (cykl pt. Głoski), których związek z motywem językowym jest potwierdzony i zaprojektowany przez tytuł. Poświęcę tym pracom nieco więcej uwagi, jako że zainteresowania i wieloletnie eksploracje graficzne kuratorki wystawy stały się impulsem do zorganizowania festiwalu.

Prace Koreckiej można potraktować jako studia $\mathrm{z}$ dziedziny liternictwa ${ }^{10}$, przekraczają one jednak tradycyjne granice grafiki artystycznej ze względu

9 Spośród ogromnej liczby prac poświęconych w ostatnich latach rozważaniom na temat pojęć „podmiotu” czy „osoby” wymienię tu tytułem przykładu następujące publikacje: Z problemów podmiotowości w literaturze polskiej XX wieku, red. M. Lalak, Szczecin 1991; Ja, autor. Sytuacja podmiotu w polskiej literaturze wspótczesnej, red. D. Śnieżko, Warszawa 1996; Osoba w literaturze i komunikacji literackiej, red. E. Balcerzan, W. Bolecki, Warszawa 2000; R. Nycz, Osoba w nowoczesnej literaturze, [w:] idem, Literatura jako trop rzeczywistości. Poetyka epifanii $w$ nowoczesnej literaturze polskiej, Kraków 2001; A. Elliott, Koncepcje „Ja”, tłum. S. Królak, Warszawa 2007; Podmiot w języku i w kulturze, red. J. Bartmiński, A. Pajdzińska, Lublin 2008. Do kwestii tożsamości i integralności podmiotu odnoszę się w studium: T. Dobrzyńska, Podmiot utworu poetyckiego wobec kwestii spójności oraz interpretacji tekstu, [w:] eadem, Tekst poetycki i jego konteksty. Zbiór studiów, IBL PAN, Warszawa 2015.

${ }_{10}$ Niektóre z tych prac były wcześniej eksponowane na wystawie autorskiej Joanny Koreckiej pt. Jaknowone - Niewysłowione w warszawskim Domu Artysty Plastyka (lipiec 2019). 
nie tylko na zerwanie z funkcją użytkową, ale też na twórcze przekształcenia motywów liter. Pod względem semiotycznym przekształcenia te sprowadzają się w pierwszym rzędzie do stłumienia symbolicznej funkcji znaku, czyli konwencjonalnej relacji „dana litera - określona głoska”, a towarzyszy temu uwydatnienie wartości indeksalnych znaku. Większość z tych prac zdaje się wyrastać ze sztuki plakatu i nawiązuje do niej wysmakowaną kompozycją form, kolorów i faktur. Ale są one raczej odwrotnością zasad tej sztuki, ponieważ autorka stara się z reguły uwalniać kształty obrazowanych liter od balastu znaczeń symbolicznych i opozycji znaczeniowych, jakimi obrosły w kulturze, a istotą sztuki plakatu jest przecież intensyfikacja semantyki przekazu z wykorzystaniem zastanych kodów. W miejsce gry konwencjami i typowego dla plakatu skrótowego ewokowania konotacji kulturowych artystka proponuje wykorzystanie indeksalnych nacechowań form graficznych liter oraz narzucanie ich układom własnych sensów, a wykorzystuje przy tym semantyczny potencjał tytułów kompozycji.

W kilku pracach Korecka bada samo tworzywo liter, podejmując próby docierania do tej fazy pierwotnego doświadczenia, w której postać znaku wyłania się ze świata materialnego, a sam znak nie jest jeszcze utrwalony w swej konwencjonalnej formie. Powrót do tego etapu doświadczeń przypomina radosne obcowanie dzieci z kształtami i barwami, z których ich wyobraźnia zdolna będzie tworzyć później własne „języki” czy kody, zanim $\mathrm{w}$ procesie edukacji przyswoją sobie gotowe wytwory rodzimej kultury etnicznej. Sensualnie doznawane formy kryją w sobie wówczas bogatą potencjalność, są jeszcze bezpośrednio związane z podmiotem nimi operującym i nasycone jego emocjami. Ich bogata i spontanicznie wyłaniająca się indeksalność, ukryte w nich rysy ikoniczne poprzedzają etap identyfikacji znaku z regułami narzucanymi przez system symboliczny obowiązujący w życiu zbiorowym.

Dekonstrukcja, jaką przeprowadza Joanna Korecka, przypomina dążenia antropologów kultury badających początki pisma i notacji cyfrowej. Podejmowana przez nią próba dotarcia do materii kształtów, z których powstawały znaki graficzne alfabetu, zanim stały się znakami, przywodzi na myśl fascynację niektórych poetów autonomiczną materią dźwięków języka 
(por. zaumnyj jazyk $k^{11}$ ) oraz etymologią i pierwotną mową (por. Słopiewnie Juliana Tuwima). Te pierwotne formy obcowania $\mathrm{z}$ tworzywem językowym utrwalone są w mantrach i w glosolaliach ludowej poezji.

Litery, uwolnione od konwencjonalnych funkcji, które czynią z nich graficzne odpowiedniki głosek i elementy zapisu słów, zaczynają żyć w obrazach Koreckiej własnym życiem. Stając się autonomicznymi bytami, zyskują możliwość wyrażania emocji, swobodnie przemieszczają się i tworzą różne układy. Mogą się w sposób dowolny przekształcać, objawiając umiejętności niemal akrobatyczne. Bywają też uczestnikami zagadkowych zdarzeń, których niejasny sens można domniemywać z ich odkształceń. Zdają się ulegać animizacji lub też poddają się interpretacji antropomorfizującej - tak jest

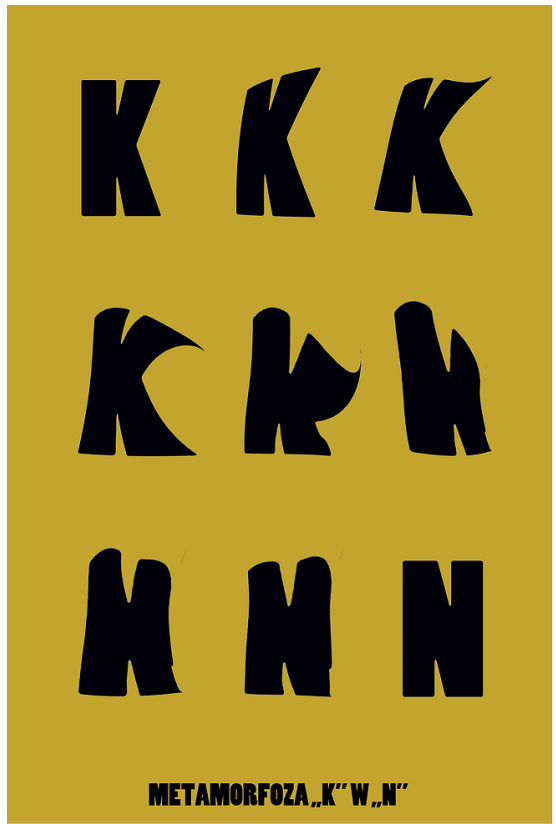

Il. 6. Joanna Korecka, Metamorfoza K w N w przypadku kompozycji opatrzonej tytułem Metamorfoza KwN (il. 6).

Praca ta - oparta na wcześniej opisanej operacji semiotycznej zacierania symbolicznych znaczeń i uwydatniania indeksalnych aspektów znaku - kwestionuje leżącą u podstaw każdego kodu zasadę opozycji, która określa funkcję poszczególnych znaków graficznych w systemie pisma. Pokazuje płynne przejście między przeciwstawnymi kształtami, sugerując równocześnie, że sprzeczności są do przezwyciężenia, a transmutacja możliwa.

Niektóre zabiegi stosowane w pracach Koreckiej zdają się odnosić do wątków myślowych leżących u podstaw współczesnej narratologii. Artystka traktuje znaki graficzne

${ }^{11}$ Zaumnyj jazyk (ros. 'język pozarozumowy') to propagowane przez rosyjskich futurystów swobodne sekwencje artykułowanych głosek, wyalienowane z konwencjonalnych funkcji w słowach i zdaniach. Zob. Zaumnyj jazyk [hasło], [w:] Słownik terminów literackich, red. J. Sławiński, Wrocław 1976. 
jako byty wyzwalające się spod presji kodu albo jeszcze niewtłoczone $\mathrm{w}$ swe ostateczne role symboliczne. Przedstawia różne konfiguracje tych liter-nieliter i tworzy z ich układów domniemane sekwencje zdarzeniowe. Wykorzystuje przy tym nawyki interpretacyjne odbiorcy zaprawionego w poszukiwaniu koherentnych sensów i znającego utrwalone szablony narracyjne eksplorowane w wielu tekstach kultury. Takie „historie liter” mają niekiedy zabarwienie humorystyczne i można w nich odnaleźć nutę ironii.

Inne prace graficzne Koreckiej odkrywają w literach ich metonimiczne związki z wyrazami i z komunikacją językową. Środkami plastycznymi - samym układem liter i kolorem - obrazują zjawiska językowe wyższego rzędu: treść sądu, istotę aktu mowy, styl wypowiedzi, funkcję języka. Indeksalne wartości znaków graficznych wykorzystywane są do ewokowania naddanych przenośnych znaczeń. Takie figuralne traktowanie motywów głoskowych znaleźć można w pracach pt. Myśl, Jedno krótkie słowo, Logorea, Funkcja fatyczna, których interpretacje ukierunkowane są przez tytuły.

$* * *$

W niektórych dziełach graficznych czy malarskich wystawianych w ramach festiwalu pojawiają się już nie poszczególne litery, ale pełne wyrażenia wkomponowane w obraz i stanowiące jego integralną część. Duża, białoczarna kompozycja abstrakcyjna Stanisława Młodożeńca (il. 7) zdaje się przedstawiać labiryntowy układ ścieżek i placów wypełnionych napisami, niby plan miasta z oznaczonymi nazwami ulic czy skwerów. Wśród oznakowanych przestrzeni można znaleźć warszawskie Łazienki, londyński Hyde Park i nowojorski Central Park; inne napisy sugerują raczej, że może to być schemat przestrzeni zakodowanej w pamięci człowieka wraz z odniesieniami do ważnych dla niego twórców czy obiektów, z zapamiętanymi ciągami słów tworzących jakieś prywatnie umotywowane układy.

Kompozycja ta przypomina też w całości powiększone odbicie palca, z zaznaczonymi liniami papilarnymi. To skojarzenie nasuwa myśl o obecności człowieka świecie, potwierdzanej aktami nazywania czy zostawiania językowych śladów pamięciowych w przestrzeni.

Właśnie te akty nazywania czy słowa skojarzone z miejscami sprawiają, że amorficzna przestrzeń przeistacza się na obrazie Młodożeńca w przestrzeń włączoną do czyjegoś świata, zmienioną w prywatną antroposferę. Przywodzi to na myśl praktykę językowego zawłaszczania miejsc, znaną 


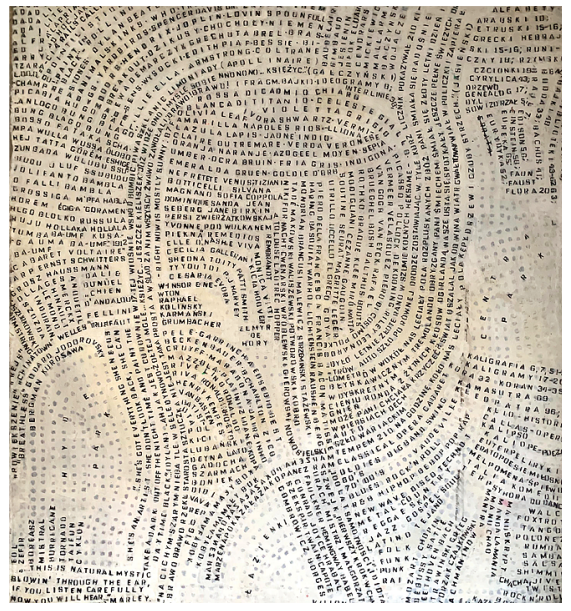

Il. 7. Stanisław Młodożeniec, Inspirues (2004) antropologom kultury, historykom czy politologom analizującym oznakowanie miast, ulic, placów, obiektów topograficznych itp. przez grupy etniczne zasiedziałe w jakiejś przestrzeni lub dokonujące jej aneksji. W proponowanej tu lekturze obraz Młodożeńca przekształca się z kompozycji abstrakcyjnej w dzieło o cechach mimetycznych i - opartej na ikoniczności - strukturze diagramu. Staje się rzutem pionowym miejsca włączonego do świata człowieka, ukazującym jego osobistą topografię.

Inne funkcje pełnią napisy w niewielkim, przypominającym okrągłe lustro obrazie olejnym Arnolda Ananicziusa Zwierciadło z imionami (il. 8), nawiązującym swą formą i fakturą oraz wyszukaną grą znaczeń do malarstwa niderlandzkiego. Obraz przedstawia ciemne wnętrze objawiające się w wypukłym lustrze - przestrzeń istniejącą jedynie pośrednio, bo przetworzoną w odbiciu. Mrok tego fantomowego wnętrza ledwo rozjaśniają dwa źródła światła: światło słoneczne padające $z$ okna, wraz z jego odbiciem po przeciwnej stronie wnętrza, oraz nikłe światełko umieszczonej centralnie świecy.

Kompozycja pełna jest odniesień intertekstualnych - przywołuje pamięć wyrafinowanych kompozycji Jana van Eycka czy innych starych mistrzów wprowadzających motyw odbić w wypukłym zwierciadle ${ }^{12}$. Nawiązania do van Eycka są w obrazie Ananicziusa najwyraźniejsze - w obrazie Małżeństwo Arnolfinich też występuje motyw świecy. Van Eyck umieścił w swej kompozycji pięknie wystylizowany podpis, którego odpowiedniki także odnaleźć

12 Zob. przede wszystkim odbicia wnętrza w wypukłym zwierciadle oraz okno wpuszczające światło słoneczne na obrazach Jana van Eycka Małżeństwo Arnolfinich (1434) i w skrzydle tryptyku Roberta Campina, przedstawiającym Jana Chrzciciela z fundatorem dzieła, Henrykiem von Verl (1438). Motyw wypukłego lustra wprowadził też Memling na obrazie Madonny z Dzieciątkiem (1487). 
można w kompozycji Ananicziusa w jego obrazie, na tle ciemnej przestrzeni, zaznaczają się delikatne złociste smugi napisów, a są to, dyskretnie wpisane w obraz, 24 nazwiska malarzy, pisarzy czy innych wybitnych twórców, stanowiących prywatny panteon autora ${ }^{13}$ (jest ich tylu, ile liter w łacińskim alfabecie, a to z kolei uzmysławia rolę alfabetu jako tekstu kultury, który cechuje się kompletnością, a zarazem umożliwia porządkowanie różnych zjawisk i zestawianie zbiorów). Na analogie $\mathrm{z}$ malarstwem niderlandzkim naprowadza też motyw okna i światła słonecznego,

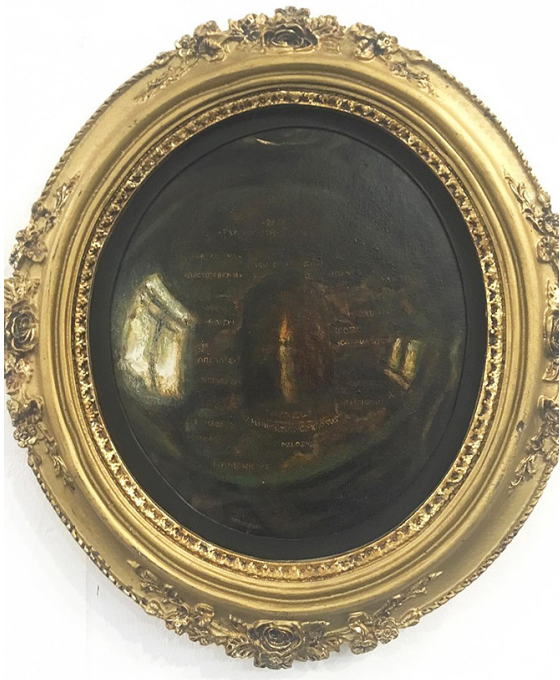

Il. 8. Arnold Ananiczius, Zwierciadło $\mathrm{z}$ imionami co u dawnych mistrzów symbolizowało obecność transcendentnej świadomości ${ }^{14}$. W sumie ta przedstawiona przez Ananicziusa niematerialna zjawiskowa przestrzeń - dostrzeżona w odbiciach, niejako w akcie iluminacji - staje się wehikułem czasu. Zyskuje charakter sakralny jako miejsce pamięci uobecniające wielkich patronów.

Spora część prac eksponowanych na wystawie nawiązuje do pojęć językowych w sposób pośredni, nie eksponując słów czy liter w samej przestrzeni obrazu. Odniesienia językowe do aktów mowy czy form wypowiedzi są natomiast zawarte w tytułach, które ukierunkowują odbiór kompozycji. Omawiane teraz prace wykorzystują zarówno funkcję tytułu sugerującego odniesienie do komunikacji językowej, jak też dający się wyzwolić potencjał

${ }^{13}$ Są wśród nich: Oskar Miłosz, Czesław Miłosz, Zbigniew Herbert i Andriej Tarkowski.

14 Zob. np. obraz Rembrandta Medytujący filozof, który przedstawia mężczyznę siedzącego przy oknie i czytającego Biblię. Padające z lewej strony światło słoneczne staje się niejako gwarantem poprawnych odczytań treści biblijnych. Symbolika taka stała się szczególnie nośna w kraju protestanckim, dopuszczającym indywidualną interpretację Pisma. 
interakcji różnych środków wyrazu, który działa podobnie do przenośni stosowanych w wypowiedziach językowych i bywa określany jako „metafora transsemiotyczna"15.

Sensotwórczy potencjał tytułu nawiązującego do komunikacji językowej wykorzystuje m.in. Roman Kirilenko w trzech kompozycjach z cyklu Obsesje - szukajac swojego słowa (il. 9) oraz w obrazach List do przyjaciela (1 i 2). Środkami malarskimi artysta wyraża w tych pracach niejasne napięcia emocjonalne towarzyszące kontaktom międzyludzkim, gdy trudno znaleźć adekwatny wyraz myśli i osobistych przeżyć w stereotypowych aktach porozumienia językowego.

Podobna interakcja tytułu z treścią obrazu zachodzi w kompozycji Magdaleny Pastuszak Znak diakrytyczny (il. 10).

W tej grupie kompozycji mieści się też praca Koreckiej pt. Bluzg (il. 11), oparta na zasadzie obrazowego odwzorowania aktu mowy. Użyte w tytule tego obrazu słowo jest w swym pierwotnym sensie synonimem „chlapnięcia” czy „bryzgu”, ale w znaczeniu pochodnym stanowi zleksykalizowaną metaforę językową, która oznacza agresywną i wulgarną wypowiedź16. Jej plastycznym odpowiednikiem na obrazie Koreckiej stają się gwałtownie poprowadzone, opadające ciemne smugi oraz ostre kontrasty czerni i bieli. $\mathrm{W}$ rezultacie interakcji tytułu $\mathrm{z}$ obrazem zachodzi niejako spiętrzenie znaczeń przenośnych: metaforyzacja zawarta w wyrażeniu „bluzg” znajduje niejako przedłużenie w metaforze malarskiej.

Istotne ukierunkowanie sensu wnosi też tytuł kompozycji Koreckiej: Paplanina (il. 12). Praca ta - na prawach metafory transsemiotycznej - wyraża poprzez bezładne splątanie linii chaotyczną mowę, czczą gadaninę. W języku taki sposób mówienia profilowany jest jako zjawisko negatywne,

15 Zob. E. Szczęsna, Metafora transsemiotyczna, „Pamiętnik Literacki” 2004, z. 2.

${ }_{16}$ Mały słownik języka polskiego pod redakcją Stanisława Skorupki, Haliny Auderskiej i Zofii Łępickiej (Warszawa 1969) podaje: „bluzgać - 'tryskać, chlustać, rozpryskiwać się’ [...], przen. bluzgać przekleństwami. Formacja słowotwórcza bluzg utworzona została na zasadzie odcięcia końcówki czasownika, czyli przy użyciu tzw. formantu paradygmatycznego; jest to wyraz nacechowany stylistycznie - kolokwialny, czy wręcz wulgarny. Synonimem tej formacji jest frazeologizm obrzucić kogoś błotem, który również powstał na zasadzie zleksykalizowanej przenośni”. 


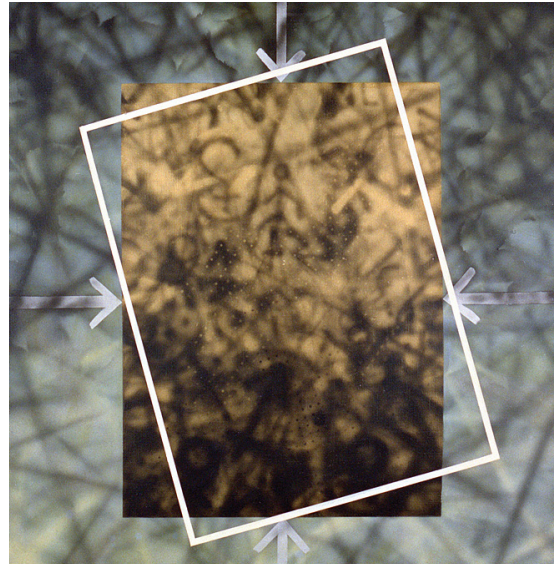

Il. 9. Roman Kirilenko, Obsesje - szukając swojego słowa

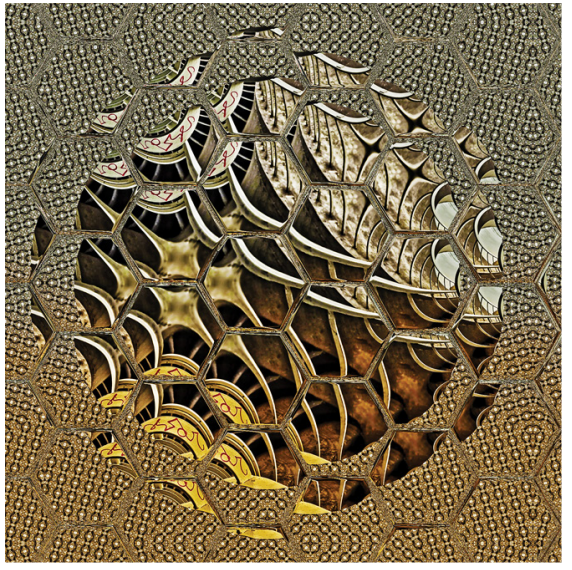

Il. 10. Magdalena Pastuszak, Znak diakrytyczny

a pejoratywna ocena zostaje zasygnalizowana przy użyciu środków leksykalnych i słowotwórczych ${ }^{17}$.

Figuralne przekształcania sensów oparte są niekiedy na zasadach metonimicznych, których motywacji należy szukać w powiązaniach rzeczy $\mathrm{z}$ działaniami, w symultanicznym występowaniu zjawisk, w ich związkach przyczynowo-skutkowych. Dzięki tym koincydencjom jedno zjawisko staje się znakiem wywoławczym drugiego, wykorzystywany jest więc skrót myślowy, możliwy dzięki przywołaniu utrwalonej wiedzy o świecie.

Do takich metonimicznych związków odwołuje się instalacja Koreckiej plansza pt. Czytajac „Dlane” Jakuba przedstawia tomiki poetyckie otwarte na różnych stronach i odtwarza proces lektury wierszy Jakuba Fišera Dlane (czesk. 'dłonie, ręce'). Normalny przebieg takiego procesu to wielokrotne nielinearne obcowanie $z$ fascynującą poezją, co ilustrują liczne egzemplarze książki ukazanej niejako w symultanicznych aktach czytania. Dołączony do instalacji utwór Fišera daje wyobrażenie o tej poezji - bogatej w sensy symboliczne i figuralne:

17 Paplać - 'mówić dużo i bez potrzeby; pleść, bajdurzyć'; paplanina - 'beztreściowe mówienie, niepoważna rozmowa; plotki’. Zob. ibidem. 


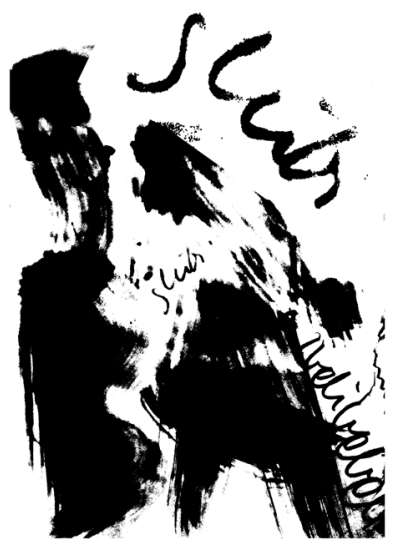

Il. 11. Joanna Korecka, Bluzg

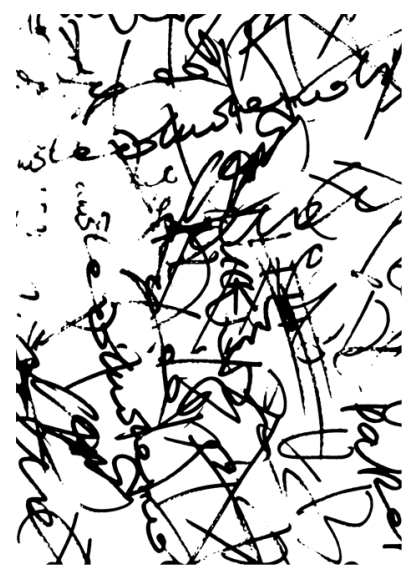

Il. 12. Joanna Korecka, Paplanina

\begin{abstract}
Milcz w milczeniu
ustami

oczami

we wszystkich językach

w płonącym krzewie

w półksiężycu

w cierniowej koronie

milcz w świetle ciemności

pomimo milczenia ${ }^{18}$
\end{abstract}

Podobnie synekdochiczno-metonimiczną motywację przypisać można kompozycjom Bożeny Korulskiej z cyklu Nieskończoność - Księga Szkocka (I, II, III, IV, V, VI), obrazującym przy użyciu abstrakcyjnych znaków zadania matematyczne wymagające rozwiązania, zanotowane w brulionie przez uczonych spotykających się od połowy lat 30. ubiegłego wieku w restauracji Szkocka we Lwowie. Jest to z kolei studium przekodowania pierwotnych zapisów na umowną notację przywołującą na myśl symbole stosowane w naukach ścisłych. Praca operuje znakami ikonicznymi nadbudowanymi

${ }_{18}$ Wiersz w przekładzie-parafrazie Joanny Koreckiej. 
nad wartościami indeksalnymi pierwowzorów i scala poszczególne odwzorowania przy użyciu struktury diagramu.

Do codziennych praktyk życiowych, wspieranych użyciem komunikatów do siebie samego, nawiązuje kompozycja plastyczna Koreckiej pt. Zbiór zadań z życia, przedstawiająca rodzaj segregatora: konstrukcję złożoną z pionowych skrytek, do których wsunięte zostały karteczki. Instalacja wprowadza ironiczny dystans wobec metodycznych i systematycznych prób poszufladkowania czynności zaplanowanych przez człowieka próbującego zapanować nad swymi licznymi obowiązkami. Takie usiłowania są jednak wręcz groteskowe, bo z góry skazane na niepowodzenie w obliczu nieogarnionego w swym bogactwie życia. Ironia jest już ukryta w tytule, nawiązującym do tytułów pomocy naukowych w rodzaju: „Zbiór zadań z geometrii”.

Jak to wielokrotnie dało się zauważyć w powyższych analizach i jak tego dowodzi powszednie obcowanie ze sztuką, najczęściej stosowaną formą współdziałania znaczeń słów z treścią obrazów jest użycie tytułu. Tak jest w przypadku wszelkich wytworów artystycznych: kompozycji muzycznych, układów tanecznych czy rzeźb, filmów, sztuk teatralnych i wszelkich utworów literackich, których tytuły ukierunkowują interpretację dzieł. Kwestia ta wymaga osobnego omówienia, a zatem oddzielenie językowej formuły użytej w tytule od plastycznej kompozycji niezawierającej tworzywa językowego będzie podstawą wyodrębnienia osobnej grupy analizowanych tu dzieł.

Mając na uwadze zastosowaną w tym artykule zasadę porządkowania materiału, omawianą teraz grupę prac można by scharakteryzować jako teksty kultury jednorodne pod względem użytego tworzywa. Elementy językowe dołączone do tych dzieł w postaci tytułu stoją na zewnątrz samej kompozycji plastycznej, ale wchodzą z nią w głęboki związek na poziomie znaczeń. Tytuł nie tylko identyfikuje dzieło (jest niczym imię nadane człowiekowi w akcie performatywnym), ale pełni też funkcję metatekstową, określając m.in. sens tekstu czy (jak w interesującym nas przypadku) obrazu' ${ }^{19}$.

19 Funkcje tytułu obrazu oraz historię użycia tego komponentu, który późno zyskał status elementu towarzyszącego dziełu z woli twórcy i określającego jego sens, analizuje Mieczysław Wallis; zob. M. Wallis, O tytułach dzieł sztuki, [w:] idem, Sztuki i znaki. Pisma semiotyczne, Warszawa 1983. Tytułom tekstów literackich 
Gdy dzieło plastyczne zostaje opatrzone tytułem, powstaje nieusuwalne napięcie między precyzyjnymi znaczeniami kodu językowego oraz z gruntu odmiennymi w swym charakterze znakowym - plastycznymi środkami wyrazu i ich unikalnymi konfiguracjami w dziele. Funkcja tytułu jako metatekstu komentującego tekst stanowi pochodną funkcji języka w kulturze. Jak dowodzą semiotycy i antropolodzy, to język naturalny jest podstawowym kodem komunikacji, dysponującym precyzyjnymi, a nieznanymi innym systemom znaków, środkami ${ }^{20}$. To właśnie system języka dostarcza interpretantów (środków eksplikacji sensów), umożliwiając działania analityczne skoncentrowane na wszelkich tekstach kultury - obrazach, rzeźbach, utworach muzycznych, układach baletowych itp. Choć możliwe jest dążenie do różnych przekładów intermedialnych w obszarze kultury ${ }^{21}$, to najbardziej naturalny i najczęściej wykorzystywany jest kierunek transpozycji treści od dowolnego rodzaju dzieła do jego odpowiednika w języku naturalnym (zob. libretta oper i baletów, streszczenia filmów, dramatów czy spektakli teatralnych, ekfrazy). Naturę językową ma też wszelka działalność teoretyczna i krytyczna: teoria i krytyka sztuki, muzykologia i teatrologia, działalność recenzentów poszczególnych odmian sztuki. Precyzja pojęciowa języka umożliwia identyfikację treści przedstawień obrazowych, uruchamiając równocześnie asocjacje pojęciowe związane ze słowami wchodzącymi

poświęciła swe studium Danuta Danek; zob. D. Danek, O tytule utworu literackiego, „Pamiętnik Literacki” 1972, z. 4.

20 Poza precyzją semantyczną jednostek leksykalnych i konstrukcji gramatycznych wymienię tu przede wszystkim negację i skonwencjonalizowane typy modalności, jak twierdzenie, rozkazywanie, przypuszczanie, wątpienie, przyjmowanie pewnych treści warunkowo itp., itd.

${ }^{21}$ Na przykład powieść Prospera Mérimégo Carmen, przetransponowana na operę Georges’a Bizeta, obrazy wyobrażone dźwiękami w Obrazkach $z$ wystawy Modesta Musorgskiego, dramat Szekspira Burza w wersji baletowej do muzyki Henry'ego Purcella, Thomasa Tallisa, Roberta Johnsona, Matthew Locke'a i Michela van der Aa, w choreografii Krzysztofa Pastora (wykonany w warszawskiej Operze Narodowej 23 kwietnia 2016 roku w ramach VIII Dni Sztuki Tańca), ekranizacje i filmowe parafrazy Hamleta, Romea i Julii czy Makbeta itp., itd. Tego typu intermedialnym translacjom i parafrazom - zwłaszcza tym, dla których punktem wyjścia są teksty literackie poświęcony jest zbiór studiów Rejony twórczej zmiany. Tekst. Adaptacja. Medialna re-kreacja, red. B. Pawłowska-Jądrzyk, K. Gołos-Dąbrowska, Warszawa 2019. 
w języku w różne związki i będącymi nośnikami konotacji. Sensotwórcze działanie tytułu widoczne jest np. w abstrakcyjnej kompozycji Bożeny Korulskiej pt. Nieskończoność (il. 13).

Takie oddziaływania widać zresztą także we wcześniej wymienianych pracach, w których litery czy zapis słów zostały artystycznie przetworzone w samym obrazie, a tytuł przypisany dziełu generuje sens dający się uzyskać jedynie dzięki specyficznym możliwościom języka. Za przykład niech posłuży kompozycja literowa Koreckiej pt. Logorea (il. 14).

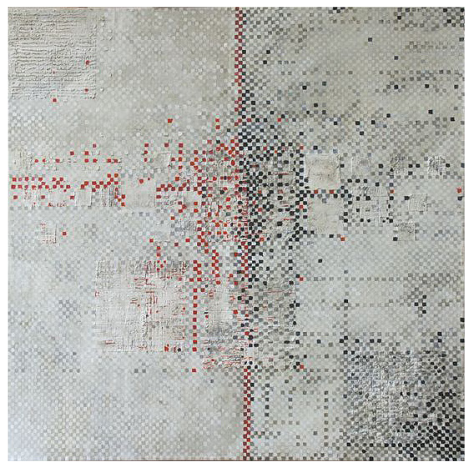

Il. 13. Bożena Korulska, Nieskończoność

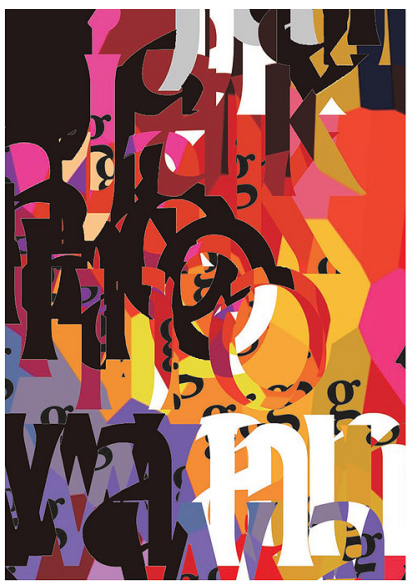

Il. 14. Joanna Korecka, Logorea

Ów tytuł nie tylko narzuca treść referencjalną kompozycji literowej, odnosząc ją do mówienia, ale (podobnie jak w przypadku obrazu Bluzg) dookreśla też to mówienie negatywnie, wykorzystując zabarwienie stylistyczne słowa. Tytułowy termin w wyszukany sposób (bo to pożyczka z języka greckiego, dostarczającego polszczyźnie terminów naukowych) określa szczególne zachowanie językowe: logorea to, jak podaje słownik, „słowotok, patologicznie nadmierna, często bezładna gadatliwość"22.

22 Zob. W. Kopaliński, Słownik wyrazów obcych i zwrotów obcojęzycznych $z$ almanachem, cz. 1, Warszawa 2007, s. 342. 
Projektującą rolę tytułu niosącego całe bogactwo znaczeń elementów języka można znaleźć w wielu obrazach pokazanych na wystawie, a w kilku z nich jest to jedyny sposób połączenia słów i obrazu. Tak jest np. w przypadku kompozycji Marii Kalety Natura w mikroskali.

W tej grupie prac mieszczą się też studia z cyklu Infinity of art Bożenny Leszczyńskiej (il. 15-16). Przedstawiony na wystawie obraz to wyobrażenie przedmiotu o urzekających barwach i kształcie, przypominającego cenny minerał. Dzięki tytułowi obraz ten staje się metaforyczną quasi-deskrypcją dominium sztuki - zachwycającego zjawiska nieograniczonego w swym zasięgu i bogactwie środków wyrazu. Studium to, interpretowane w obrębie cyklu, ukazuje nieograniczone możliwości transmutacji obrazu, który w coraz to inny sposób ujmuje niby ten sam przedmiot, dając wyraz zmiennej naturze postrzegania rzeczywistości przez artystkę, dokonującą analizy wyobrażeń przedmiotu od ujęcia quasi-realistycznego do abstrakcji. Świat zewnętrzny objawia się tu jako obiekt indywidualnego oglądu, w którym impulsy zewnętrzne są przetwarzane pod wpływem czynników subiektywnych w wizję artystyczną.

Semantykę tytułu ciekawie wykorzystuje w swoich pracach Mariusz Szymański - autor wyrazistych obrazów publicystycznych i animacji poklatkowej utworzonej z serii obrazów (jedna z prac eksponowanych na wystawie
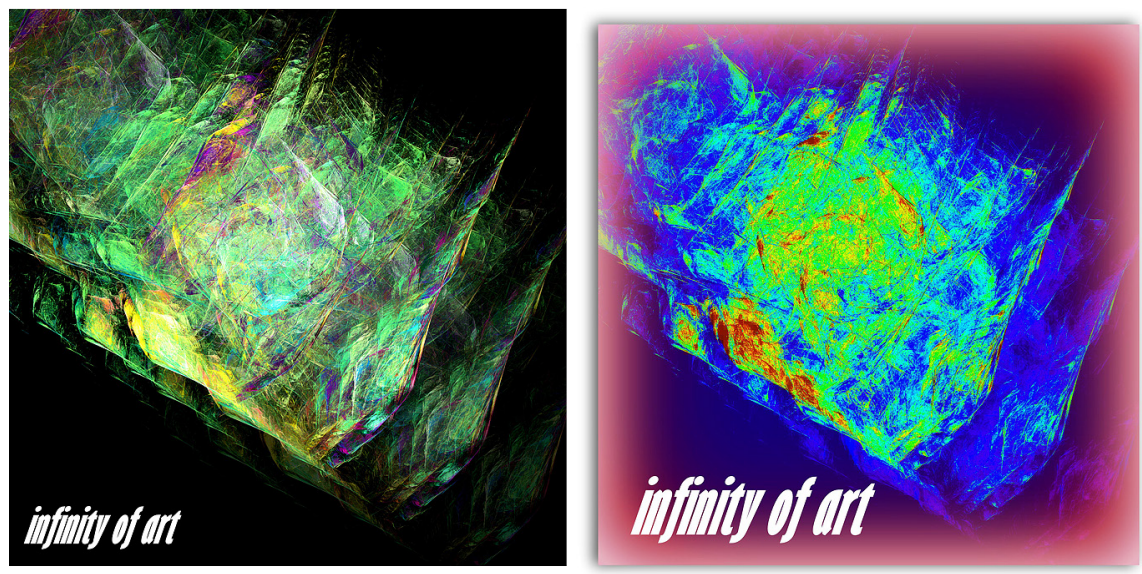

Il. 15-16. Bożenna Leszczyńska, Infinity of art 
to wizualizacja piosenki poznańskiego zespołu Amor Con Chordes). Ze względu na rozważaną teraz funkcję tytułu zwrócę uwagę na trzy jego dzieła.

Na jednym z obrazów Szymańskiego ukazane jest nowoczesne miasto, o gęstej zabudowie wieżowców, w których mieszkają czy pracują tysiące ludzi. Ale powszedniość wielkomiejskiej scenerii zostaje zakłócona: $\mathrm{z}$ jednego z dachów snajper celuje w kierunku domów. Obraz jest czytelny referencjalnie i ma oczywistą wymowę publicystyczną, ale podpis pod obrazem: Nie ma jak $w$ domu, wnosi ton sarkazmu, każe myśleć o paradoksalnym zespoleniu tradycyjnego pojęcia „domu” - miejsca bezpiecznego schronienia - z jego przeciwieństwem. Autor zwraca uwagę na fakt, że zamachy terrorystyczne przeniosły się do dużych skupisk ludzkich, do wielkich miast. Dzięki tytułowi kompozycja Szymańskiego wyraźnie podpowiada odczytanie, że we współczesnym świecie „zadomowił się” terroryzm i obrazuje zmianę świadomości mieszkańców miast po zamachach terrorystycznych - poczucie stałego zagrożenia.

Inny obraz Szymańskiego też podejmuje temat terroryzmu (il. 17). Przedstawia spokojny tłum zgromadzony na rozległej przestrzeni placu przed bazyliką św. Piotra w Rzymie. Na tym tle ukazana została - zwrócona twarzą do obserwatora - mała dziewczynka w kamizelce-nosidłach wypełnionej jakimiś przedmiotami. Wydaje się, że to mała sprzedawczyni oferująca jakieś pamiątki pielgrzymom. Przy bliższym oglądzie okazuje

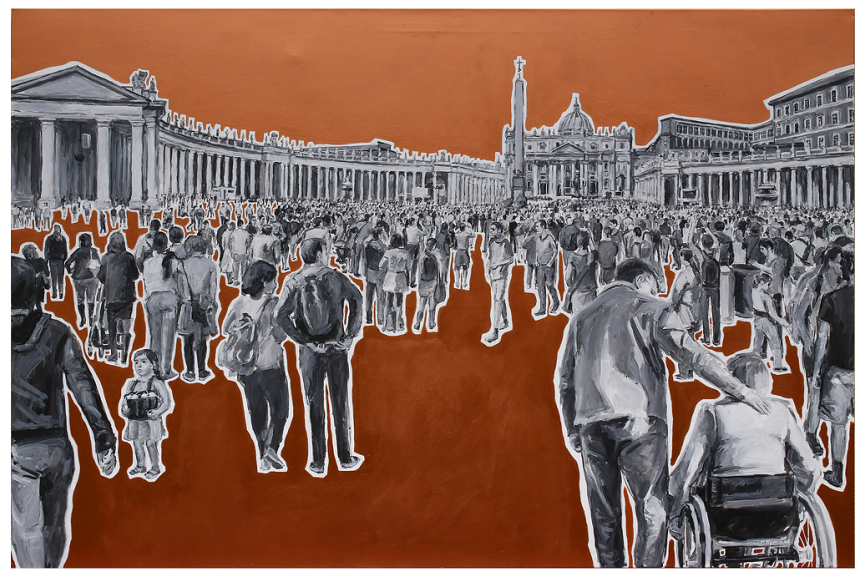

Il. 17. Mariusz Szymański, Dziewczynka z zapałkami 
się, że dziewczynka trzyma w ręku zapalnik, a z kamizelki wystają ładunki wybuchowe... Podpis Dziewczynka z zapałkami przenosi na ten obraz cały ładunek emocjonalny baśni Hansa Christiana Andersena i jej humanitarną wymowę, a równocześnie tak zobrazowana scena staje się szyderczym komentarzem do stereotypowego rozumienia tytułowego motywu, ponieważ dziewczynka na obrazie to nie tylko biedne dziecko, ale też - prawdopodobnie nieświadome - narzędzie terroryzmu. Jej rola jest ambiwalentna: zginie sama, ale spowoduje też śmierć niewinnych ludzi skupionych na placu.

Kompozycja Szymańskiego Stacja VIII (il. 18) ukazuje z kolei tłum obojętnych młodych ludzi, pośród których upada samotna postać dźwigająca belkę - Chrystus w długiej szacie i koronie cierniowej, łatwo rozpoznawalny w tej scenie. Tytuł - przeniesiony z jednej ze stacji drogi krzyżowej (Chrystus upada pod krzyżem) - odnosi dzieło do ikonografii chrześcijańskiej i do liturgii drogi krzyżowej, a pośrednio do Ewangelii ${ }^{23}$. Moc perswazyjna obrazu wynika $\mathrm{z}$ figuralnego przetworzenia znaczeń sceny pasyjnej: nadania jej generalizującej wymowy i odniesienia do współczesności.

W obu omówionych powyżej przypadkach tytuły zostały zapożyczone na prawach cytatów $\mathrm{z}$ innych wcześniejszych dzieł: ze znanej baśni lub $\mathrm{z}$ powszechnie znanej sceny sakralnej przedstawianej w wielu tekstach kultury. To zapewniło im wyrazistość znaczeniową i uaktywniło ładunek aksjologiczny. We wszystkich obrazach Szymańskiego tytuły odgrywają decydującą rolę przy uruchomieniu sensów ironicznych, nadaniu dziełom szyderczej wymowy.

Gra semantyczna z tytułem umożliwia też działania odwrotne. Swoistym manifestem oderwania dzieła plastycznego od treści projektowanych przy użyciu słów są efektowne obrazy Wandy Hansen, oznaczone paradoksalną formułą tytułową Bez tytułu (il. 19). Taki nie-tytuł spełnia jednak identyfikacyjne funkcje tytułu i zachowuje jego zdolności sensotwórcze, podkreślając rezygnację autorki z poddania się konwencji lub jej przeświadczenie o niedającej się wysłowić, złożonej i znaczeniowo otwartej naturze przedstawionego tematu.

${ }^{23}$ Podobne ujęcie sceny - samotność umęczonego Chrystusa w tłumie obojętnych ludzi, zajętych swoimi sprawami - znaleźć można np. w kompozycji Drogi krzyżowej Pietera Bruegla starszego. 


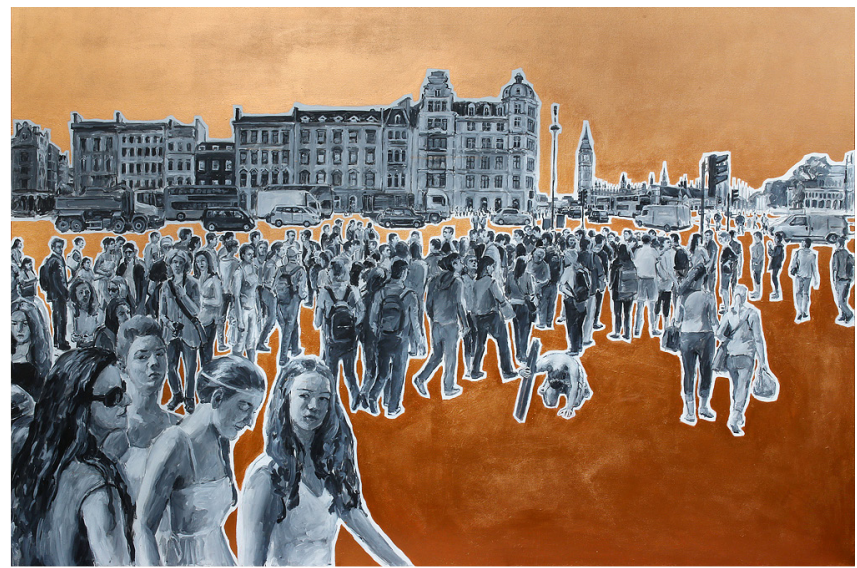

Il. 18. Mariusz Szymański, Stacja VIII

Jednym ze słów-kluczy festiwalu był „znak” - hasło pojemne, odnoszące się do różnych nośników znaczeń, funkcji znakowych i operacji znaczeniotwórczych obserwowanych w tekstach kultury, także tych dokonywanych na znakach językowych: słowach czy literach. Przegląd prac przedstawionych na wystawie zakończę przywołaniem kilku dzieł reprezentujących znakowość uchwyconą w swej pierwotnej postaci. Będą to wielkie plansze Jacka Dittwalda, nawiązujące prostą formą geometryczną koła czy trójkąta do prehistorycznych lub szamańskich znaków obrzędowych.

Intrygujące zestawienie kręgów czy kul, a wśród nich artefaktów pochodzących sprzed wieków, ukazuje Arnold Ananiczius w obrazie Krąg nicości, dysk z Fajstos i medalion księcia Gesualda $z$ Venosy (il. 20) ${ }^{24}$. Przedmioty materialne przedstawione na obrazie - synekdochy dawnych kultur i zdarzeń są niczym kapsuły sensu przerzucone w inny czas. Pozostają niezrozumiałe i tajemnicze jako symbole, które utraciły swój pierwotny sens ${ }^{25}$ - dostępne

${ }^{24}$ Autorską wykładnię treści obrazu znaleźć można w artykule: A. Ananiczius, Martwa natura z kulą nicości, „Bezkres” 2020, nr 5 (maj).

25 Wypełniony spiralnym zapisem dysk z Fajstos, odnaleziony w pałacu króla Minosa na Krecie i pochodzący z ok. 1700 roku p.n.e., został w $90 \%$ odczytany, 


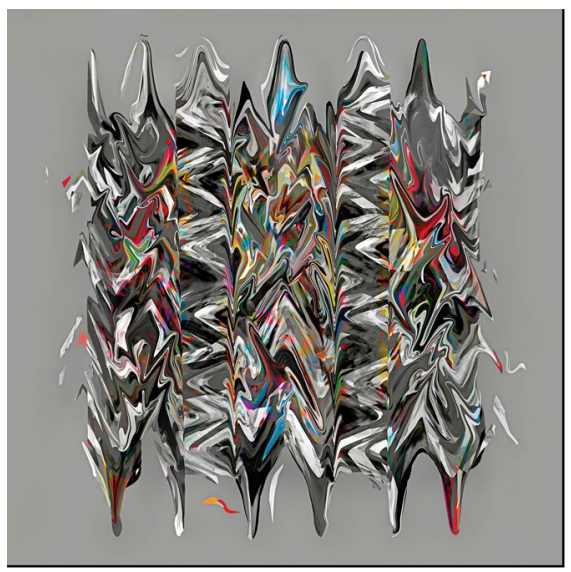

Il. 19. Wanda Hansen, obraz z cyklu Bez tytułu

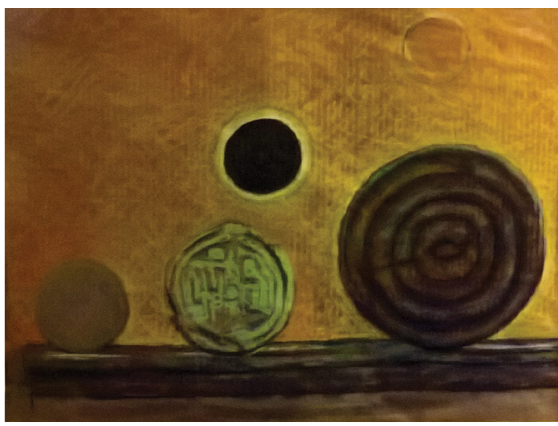

Il. 20. Arnold Ananiczius, Krąg nicości, dysk z Fajstos i medalion księcia Gesualda z Venosy

jedynie na poziomie ogólnych znaczeń referencjalnych i niejasnych nacechowań ikonicznych. Ich łączne przedstawienie uzmysławia współczesnemu odbiorcy utratę przekazów pochodzących z dawnych epok, a także naturę człowieka jako istoty nierozerwalnie zespolonej ze sferą znaczeń, nieustannie szukającej wyjaśnień i zaintrygowanej tym, co niezrozumiałe.

Dwa artefakty zestawione są na obrazie Ananicziusa z płaskim kręgiem stojącym obok nich i z niewielką bladą kulą zawieszoną w górze, którą autor określił jako bańkę mydlaną odbijającą światło. Gdyby zinterpretować symbolicznie ten najmniejszy obiekt, to wyrażałby on przemijanie, nietrwałość zjawisk i dopełniałby wnioski z rozmyślań o zacieraniu się znaczeń dysku i medalionu. Ukazany nad tymi artefaktami czarny krąg z jasną obwódką można zidentyfikować jako zaćmienie słońca, a współczesna wiedza astronomiczna podsuwa też skojarzenie z obrazem kosmicznej czarnej dziury. Użyte w tytule określenie „krąg nicości” uaktywnia mechanizm metafory i ewokuje złowieszcze treści obu alternatywnych rozpoznań, bo czarna

ale wciąż niejasna jest jego funkcja. Natomiast znaki wyryte na medalionie księcia Gesualda pozostawały niezrozumiałe dla samego właściciela - człowieka, którego los naznaczony był tragizmem. Medalion-amulet nabiera w tych okolicznościach niepokojącej mocy magicznej. 
dziura jest zjawiskiem niszczącym materię, a zaćmienie słońca od wieków budziło niepokój czy wręcz panikę i traktowane było jako kosmiczna katastrofa - zwiastun końca świata. Intertekstualnego oparcia dla owej katastroficznej wykładni obrazu słońca, które staje się czarne i zwiastuje ziemi zagładę, można szukać w Apokalipsie św. Jana, a motyw „czarnego słońca” podjęli też poeci ${ }^{26}$. Łącząc odczytania wszystkich intrygujących znaków przedstawionych na obrazie, można w nim widzieć refleksję nad wszechobecnym żywiołem zniszczenia, które dotyka sensu znaków i wszystkiego, co istnieje. Na wyzwolenie poczucia grozy zdecydowany wpływ wywiera językowa identyfikacja czarnego kręgu jako „kręgu nicości”, co znalazło wyraz w metaforycznym tytule obrazu.

\section{PODSUMOWANIE}

Festiwal Litery - Słowo, litera, znak był ważnym wydarzeniem potwierdzającym produktywność działań w intermedialnych przestrzeniach kultury - wydarzeniem poniekąd unikalnym w swym zasięgu, bo skupiającym artystów o różnych specjalnościach - zajmujących się sztuką plakatu, grafiką warsztatową, smartgrafią (najnowsza technika komputerowa), malarstwem akrylowym czy olejnym, obiektami, instalacją oraz filmem - a obliczonym również na zainteresowanie literaturoznawców i badaczy języka. Skupienie artystów wokół tytułowych haseł festiwalu i stworzenie platformy porozumienia z „ludźmi słowa” miało na celu ułatwienie obu środowiskom podjęcie działań w „strefie pogranicza” dyscyplin i prowokowało do rozważania różnych aspektów wzajemnego oddziaływania słowa i obrazu. Wystawa festiwalowa na różne sposoby ukazywała wyłanianie się czy ewokowanie znaczeń na styku „znak językowy - przekaz plastyczny”. Owa fuzja semiotyczna przyniosła wartościowe rezultaty i niewątpliwie zasługuje na uwagę badaczy obu obszarów kultury.

\section{Lista autorów dzieł plastycznych}

Arnold Ananiczius, Jacek Dittwald, Wanda Hansen, Maria Kaleta, Roman Kirilenko, Joanna Korecka, Bożena Korulska, Bożenna Leszczyńska, Joanna

${ }^{26}$ Zob. Ap 6, 12. Literackie kontynuacje wyobrażenia „słońca, które stało się czarne" przedstawia na materiale polskiej poezji Marian Stala; zob. M. Stala, Od czarnego słońca do ciemnego świecidła, „Teksty” 1980, z. 6. 
Mankiewicz, Stanisław Młodożeniec, Magdalena Pastuszak, Mariusz Szymański

\section{Bibliografia}

Arnold Ananiczius, Martwa natura z kula nicości, „Bezkres” 2020, nr 5 (maj).

Michaił Bachtin, Estetyka twórczości słownej, tłum. D. Ulicka, oprac. i wstęp E. Czaplejewicz, PIW, Warszawa 1986.

Byt. Badania interdyscyplinarne, cz. 1: Różnica - tożsamość - zmiana, red. M. Saganiak, A. Kozłowska, M. Werner, WN UKSW, Warszawa 2019.

Danuta Danek, O tytule utworu literackiego, „Pamiętnik Literacki” 1972, z. 4.

Teresa Dobrzyńska, Tekst poetycki i jego konteksty. Zbiór studiów, IBL PAN, Warszawa 2015.

Grzegorz Grochowski, Pamięć gatunków. Ponowoczesne dylematy atrybucji gatunkowej, IBL PAN, Warszawa 2018.

Anthony Elliott, Koncepcje „Ja”, tłum. S. Królak, Sic!, Warszawa 2007.

Wincenty Grajewski, Maszyny dialogowe. Szkice teoretycznoliterackie, TAiWPN Universitas, Kraków 2003.

Ja, autor. Sytuacja podmiotu w polskiej literaturze współczesnej, red. D. Śnieżko, WN Semper, Warszawa 1996.

Władysław Kopaliński, Słownik wyrazów obcych i zwrotów obcojęzycznych zalmanachem, cz. 1, Muza, Warszawa 2007.

Lettra - 2018, znak/litera. Tworzywo litera, [plakat wystawy], Biblioteka Jagiellońska, Kraków, 17.09 - 27.10.2018.

Mały słownik języka polskiego, red. S. Skorupka, H. Auderska, Z. Łępicka, WN PWN, Warszawa 1969.

Ryszard Nycz, Osoba w nowoczesnej literaturze, [w:] idem, Literatura jako trop rzeczywistości. Poetyka epifanii w nowoczesnej literaturze polskiej, TAiWPN Universitas, Kraków 2001.

Richard Ohmann, Akty mowy a definicja literatury, tłum. B. Kowalik, W. Krajka, „Pamiętnik Literacki” 1980, z. 2.

Osoba $w$ literaturze i komunikacji literackiej, red. E. Balcerzan, W. Bolecki, IBL PAN, Warszawa 2000.

Podmiot w języku i w kulturze, red. J. Bartmiński, A. Pajdzińska, WUMCS, Lublin 2008.

Rejony twórczej zmiany. Tekst. Adaptacja. Medialna re-kreacja, red. B. PawłowskaJądrzyk, K. Gołos-Dąbrowska, WN UKSW, Warszawa 2019. 
Resemblance and Difference. The Problem of Identity - Podobe i različe. Problema identičnosti, eds. T. Dobrzyńska, R. Kuncheva, foreword T. Dobrzyńska, IBL PAN - Instytut Literatury, Bułgarska Akademia Nauk, Warsaw-Sofia 2015. Słownik pojęć i tekstów kultury, red. Ewa Szczęsna, WSiP, Warszawa 2002.

Słownik terminów literackich, red. J. Sławiński, Zakład Narodowy im. Ossolińskich, Wrocław 1976.

Marian Stala, Od czarnego słońca do ciemnego świecidła, „Teksty” 1980, z. 6.

Ewa Szczęsna, Metafora transsemiotyczna, „Pamiętnik Literacki” 2004, z. 2.

Mieczysław Wallis, Napisy w malarstwie, [w:] idem, Wybór pism estetycznych,

wybór, wstęp i oprac.T. Pękala, TAiWPN Universitas, Kraków 2004.

Mieczysław Wallis, O tytułach dzieł sztuki, [w:] idem, Sztuki i znaki. Pisma semiotyczne, PIW, Warszawa 1983.

Z problemów podmiotowości w literaturze polskiej XX wieku, red. M. Lalak, WUS, Szczecin 1991.

Stefan Żółkiewski, Kultura, socjologia, semiotyka literacka, PIW, Warszawa 1979. Stefan Żółkiewski, Teksty kultury. Studia, PIW, Warszawa 1988.

Bogusław Żyłko, Semiotyka kultury. Szkoła tartusko-moskiewska, Słowo/obraz terytoria, Gdańsk 2009.

\section{Interactions between Visual Arts and Language/Literature at the Letter Festival: Word, Letter, Sign}

The article reports on the events held as part of the 'Letter Festival', which was intended as an interdisciplinary project targeted at the graphic artists and painters as well as linguistic and literary scholars, poetry being one of the areas explored. The numerous visual works shown at the art exhibition explore the sign material - letters, words and a visual representations of concepts - in a variety of ways. My analysis of these works focuses on semiotic aspects (the indexical, iconic, and symbolic function of signs) and several analogies to phenomena under intense research by modern literary scholarship (intersemiotic metaphors, identity of the subject, narrative structures, intertextual relations, ironical revaluations of meanings).

Keywords: visual art, linguistic signs, semiotics, interpretation 